\title{
LOCAL DELIVERY OF PARATHYROID HORMONE-RELATED PROTEIN-DERIVED PEPTIDES COATED ONTO A HYDROXYAPATITE-BASED IMPLANT ENHANCES BONE REGENERATION IN OLD DIABETIC RATS
}

\begin{tabular}{|c|c|}
\hline Journal: & Journal of Biomedical Materials Research: Part A \\
\hline Manuscript ID & Draft \\
\hline Wiley - Manuscript type: & Original Article \\
\hline Date Submitted by the Author: & $\mathrm{n} / \mathrm{a}$ \\
\hline Complete List of Authors: & $\begin{array}{l}\text { Ardura, Juan A; Instituto de Investigacion Sanitaria de la Fundacion } \\
\text { Jimenez Diaz, Laboratorio de Metabolismo Mineral y Óseo } \\
\text { Portal-Núñez, Sergio; Insituto de Investigación Sanitaria-Fundación } \\
\text { Jiménez Díaz, Laboratorio de Metabolismo Mineral y Óseo, Laboratorio de } \\
\text { Metabolismo Mineral y Oseo } \\
\text { Gutierrez-Rojas, Irene; Instituto de Salud Carlos III, Centro de } \\
\text { Investigaciones Biomédicas en Red de Diabetes y Enfermedades } \\
\text { Metabólicas Asociadas (CIBERDEM) } \\
\text { Lozano, Daniel; Insituto de Investigación Sanitaria-Fundación Jiménez } \\
\text { Díaz, Laboratorio de Metabolismo Mineral y Óseo } \\
\text { Sanchez-Salcedo, Sandra; Universidad Complutense, Madrid, Spain. Centro } \\
\text { de Investigación Biomédica en Red de Bioingeniería, Biomateriales y } \\
\text { Nanomedicina (CIBER-BBN), Departamento de Química Inorgánica y } \\
\text { Bioinorgánica, Facultad de Farmacia, } \\
\text { Lopez-Herradon, Ana; Instituto de Investigación Sanitaria (IIS)-Fundación } \\
\text { Jiménez Díaz and UAM Madrid, Laboratorio de Metabolismo Mineral y Oseo } \\
\text { Mulero, Francisca; Centro Nacional de Investigaciones Oncológicas (CNIO), } \\
\text { Unidad de Imagen Molecular } \\
\text { Villanueva-Peñacarrillo, Maria L; Instituto de Salud Carlos III, Centro de } \\
\text { Investigaciones Biomédicas en Red de Diabetes y Enfermedades } \\
\text { Metabólicas Asociadas (CIBERDEM), } \\
\text { Vallet-Regí, Maria; Universidad Complutense, Madrid, Spain. Centro de } \\
\text { Investigación Biomédica en Red de Bioingeniería, Biomateriales y } \\
\text { Nanomedicina (CIBER-BBN), Departamento de Química Inorgánica y } \\
\text { Bioinorgánica, Facultad de Farmacia } \\
\text { Esbrit, Pedro; Insituto de Investigación Sanitaria-Fundación Jiménez Díaz, } \\
\text { Laboratorio de Metabolismo Mineral y Óseo, Laboratorio de Metabolismo } \\
\text { Mineral y Oseo }\end{array}$ \\
\hline Keywords: & $\begin{array}{l}\mathrm{N} \text { - and C-terminal PTHrP, gelatin-glutaraldehyde-coated hydroxyapatite, } \\
\text { bone regeneration, aging, diabetes }\end{array}$ \\
\hline
\end{tabular}




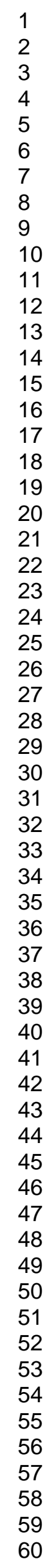

SCHOLARONE $^{\mathrm{m}}$

Manuscripts

John Wiley \& Sons, Inc. 


\title{
LOCAL DELIVERY OF PARATHYROID HORMONE-RELATED PROTEIN- DERIVED PEPTIDES COATED ONTO A HYDROXYAPATITE-BASED IMPLANT ENHANCES BONE REGENERATION IN OLD DIABETIC RATS
}

\author{
Juan Antonio Ardura ${ }^{1,2^{*}}$, Sergio Portal-Núñez ${ }^{1,2^{*}}$, Irene Gutiérrez-Rojas ${ }^{3}$, Daniel \\ Lozano $^{1,2,4}$, Sandra Sánchez-Salcedo ${ }^{4}$, Ana López-Herradón, Francisca Mulero ${ }^{5}$, \\ María L. Villanueva-Peñacarrillo ${ }^{3}$, María Vallet-Regi ${ }^{4}$ and Pedro Esbrit ${ }^{1,2}$.
}

${ }^{1}$ Laboratorio de Metabolismo Mineral y Óseo, Instituto de Investigación Sanitaria (IIS)-Fundación Jiménez Díaz and UAM, Madrid, Spain

${ }^{2}$ RETICEF- Instituto de Salud Carlos III, Madrid, Spain

${ }^{3}$ Centro de Investigaciones Biomédicas en Red de Diabetes y Enfermedades Metabólicas Asociadas (CIBERDEM), Instituto de Salud Carlos III, Madrid, Spain.

${ }^{4}$ Departamento de Química Inorgánica y Bioinorgánica, Facultad de Farmacia, Universidad Complutense, Madrid, Spain. Centro de Investigación Biomédica en Red de Bioingeniería, Biomateriales y Nanomedicina (CIBER-BBN), Spain.

${ }^{5}$ Unidad de Imagen Molecular, Centro Nacional de Investigaciones Oncológicas (CNIO), Madrid, Spain

* These authors have the same author status

Corresponding author:

Pedro Esbrit, Ph.D.

Laboratorio de Metabolismo Mineral y Óseo Instituto de Investigación Sanitaria (IIS)-Fundación Jiménez Díaz Avda. Reyes Católicos, 2 28040 Madrid (Spain) Phone: + 34915504894

e-mail: pesbrit@fjd.es 


\section{Abstract}

Diabetes mellitus (DM) and aging are associated with bone fragility and increased fracture risk. Both (1-37) N- and (107-111) C-terminal parathyroid hormone-related protein (PTHrP) exhibit osteogenic properties. We here aimed to evaluate and compare the efficacy of either PTHrP (1-37) or PTHrP (107111) loaded into gelatin-glutaraldehyde-coated hydroxyapatite (HA-Gel) foams to improve bone repair of a transcortical tibial defect in aging rats with or without DM, induced by streptozotocin injection at birth. Diabetic old rats showed bone structural deterioration compared to their age-matched controls. Histological and $\mu$-computerized tomography studies showed incomplete bone repair at 4 weeks after implantation of unloaded Ha-Gel foams in the transcortical tibial defects, mainly in old rats with DM. However, enhanced defect healing, as shown by an increase of bone volume/tissue volume and trabecular and cortical thickness and decreased trabecular separation, occurred in the presence of either PTHrP peptide in the implants in old rats with or without DM. This was accompanied by newly formed bone tissue around the osteointegrated HA-Gel implant and increased gene expression of osteocalcin and vascular endothelial growth factor (bone formation and angiogenic markers, respectively), and decreased expression of Sost gene, a negative regulator of bone formation, in the healing bone area. Our findings suggest that local delivery of PTHrP (1-37) or PTHrP (107-111) from a degradable implant is an attractive strategy to improve bone regeneration in aged and diabetic subjects.

Keywords: N- and C-terminal PTHrP, gelatin-glutaraldehyde-coated hydroxyapatite, bone regenerarion, aging, diabetes. 


\section{Introduction}

Osteoporosis, characterized by reduced bone strength and bone loss, is highly prevalent in aging westernized societies, and adversely affects the health of the elderly people by causing fragility fractures. ${ }^{1,2}$ Diabetes mellitus (DM), a metabolic disease with also increasing prevalence throughout the world, occurs frequently in the elderly, coexisting with osteoporosis. ${ }^{3}$ Chronic complications induced by DM adversely affect multiple organs, including bone, and cause an enormous medical and economic burden. ${ }^{4}$ In both type 1 and 2 DM, bone structure is altered, associated with an increased fracture risk, delayed fracture healing and potential fracture nonunion. ${ }^{5}$ Moreover, a growing body of research shows that type 2 DM increases the fracture risk independent of factors such as bone mineral density and age, currently used for predicting fractures. ${ }^{6}$ It has been hypothesized that DM-associated alterations in the skeleton might be added to those related to aging, further increasing bone fragility in diabetic old patients. In this scenario, the development of suitable approaches to improve fracture healing in these subjects is likely to have a great socioeconomic impact.

Strategies to promote bone healing after fractures include providing cell precursors, growth factors, nutrients and/or synthetic materials to the injured area to induce tissue regeneration and replace bone tissue damage. ${ }^{7}$ Materials mimicking the bone mineral composition, including biodegradable gelatinglutaraldehyde-coated hydroxyapatite foams (HA-Gel) with attractive properties for application in bone such as osteointegration and osteoconduction, have been used in bone tissue engineering. ${ }^{8}$ Adsorption of a diversity of factors to 
these materials to be used as implants has proved to improve their osteoinductive capacity. $^{9}$

Parathyroid hormone $(\mathrm{PTH})$-related protein $(\mathrm{PTHrP})$ is now emerging as an attractive cytokine in this respect. PTHrP contains a $\mathrm{N}$-terminal $1-37$ region with high homology to $\mathrm{PTH}$ and a C-terminal region -containing the highly conserved 107-111 sequence, named osteostatin for its anti-bone resorption activity $^{10}$-, displaying osteogenic features both in vitro and in vivo. ${ }^{11}$ Interestingly in this regard, systemic administration of $\mathrm{N}$ - or $\mathrm{C}$-terminal PTHrP peptides has been reported to reverse at least in part the alterations in bone structure and/or osteoblast differentiation and function in a well characterized type 1 DM mouse model and in Igf1-null mice. ${ }^{12-14}$ Moreover, we previously showed that osteostatin coating onto various implant types of ceramics or even porous titaniums accelerates healing of critical and non-critical bone defects in the long bones of adult rabbits and rats. ${ }^{15,16}$

These observations prompted us to evaluate and compare the efficacy of different PTHrP peptides to promote bone regeneration in a combined aging and DM scenario using a well characterized diabetic model. We used degradable HA-Gel foams as a template for PTHrP (1-37) or PTHrP (107-111) delivery in a cortical bone defect performed in aging rats with or without concomitant DM. 


\section{Materials and methods}

\subsection{Preparation of HA-Gel foams}

Tridimensional macroporous HA-Gel foams have been synthesized in a one-step process, using the sol-gel technique for preparing nanocrystalline HA, including a non-ionic surfactant in the synthesis, Pluronic F127 $\left(\mathrm{EO}_{106} \mathrm{PO}_{70} \mathrm{EO}_{106}\right)$, as macropore former in the accelerated evaporation induced

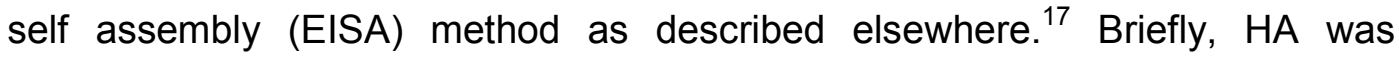
synthesized from the reaction of calcium nitrate tetrahydrate and triethylphosphite (TIP; Aldrich, Steinheim, Germany), using a molar ratio of F127:TIP of 11 . The resulting foams were coated by immersion in a $1.2 \%(\mathrm{w} / \mathrm{v})$ type A gelatin crosslinked with $0.05 \% \mathrm{w} / \mathrm{v}$ glutaraldehyde solution and then lyophilized for $24 \mathrm{~h}^{13}$ The final foams (Supplementary Fig. 1) were characterized by $\mathrm{Hg}$ porosimetry in an AutoPore III porosimeter (Micromeritics Instrument Corporation, USA), scanning electron microscopy (SEM) in a JEOL 6400 microscope (Tokyo, Japan) and X-ray diffraction (XRD) in a Philips X'Pert diffractometer using $\mathrm{Cu} \mathrm{Ka}$ radiation. Characterization details of this material have been previously reported. ${ }^{17}$

HA-Gel foams were loaded with either PTHrP (1-37) or PTHrP (107-111) (Bachem, Bubendorf, Switzerland) by soaking in a solution of each peptide (at $100 \mathrm{nM}$ ) in phosphate-buffered saline, $\mathrm{pH} 7.4$ (PBS) under stirring for $24 \mathrm{~h}$ in the cold room. ${ }^{13}$ Peptide uptake and release from these materials was determined by measuring absorbance at $280 \mathrm{~nm}$ of remaining peptide in the saline solution at different times. By using this method, the mean uptake of PTHrP (1-37) or PTHrP (107-111) by these foams after $24 \mathrm{~h}$ of loading was 
about 60 percent for each peptide, equivalent to 5.0 or $0.7 \mathrm{ng}$ peptide/mg material, respectively. Eighty percent of this amount of each PTHrP peptide was released to the surrounding medium within $1 \mathrm{~h}$, and virtually 100 percent at 2 and 5 days for PTHrP (107-111) and PTHrP (1-37), respectively.

\subsection{Animals}

Male Wistar rats were bred at our facility. Rats were placed in cages under standard conditions (room temperature $20 \pm 0.5^{\circ} \mathrm{C}$, relative humidity $55 \pm$ $5 \%$ and illumination with a $12 \mathrm{~h} / 12 \mathrm{~h}$ light/dark photoperiod), without restriction of movement, maintained on a standard pellet diet (UAR Panlab, Barcelona, Spain) and tap water ad libitum.

On the day of birth, DM was induced by a single intraperitoneal injection of streptozotocin (100 $\mu \mathrm{g} / \mathrm{g}$ of body weight) dissolved in $0.9 \% \mathrm{NaCl}$. It was previously shown that this model is characterized by a diabetic syndrome manifested by depletion of insulin stores and impaired glucose disposal in the adult. $^{18}$ Rats showing a glucose disappearance constant (K) below $2.5 \times 10^{-2} / \mathrm{min}$ after an i.v. glucose tolerance test $(50 \mathrm{mg}$ glucose $/ \mathrm{Kg}$ of body weight in $30 \mathrm{~s}$ ) performed prior to sacrifice were selected as diabetic at an age range of $18-20$ months. These animals displayed low plasma insulin, also consistent with previous studies ${ }^{18,19}$ (Fig. 1A-C). All aged rats -made diabetic or not- were of the same age (18-20 months old) and weight (Fig. 1D) by the time of the study as described below.

A group of adult rats aged 6 months was used as younger controls of the old group of rats in order to confirm the age-related bone deterioration. Intact femora from the younger and aged rats were dehydrated and embedded in 
methylmethacrylate, and 7- $\mu \mathrm{m}$ sections of the distal femur were stained with Goldner's trichrome for light microscopy examination of the distal metaphysis. ${ }^{15}$ Old diabetic rats showed less bone volume per total tissue volume ratio [bone volume (BV) over total volume (TV)] and lower trabecular thickness than the old control and the young group of rats, and decreased trabecular separation and trabecular number than the younger group (Table 1).

Animal housing and care protocols were approved by the Animal Use Committee of the IIS-Fundación Jiménez Díaz, following the European Union guidelines to decrease pain and suffering of the animals. Our protocol using a limited number of rats ( $n=5-10$ per experimental group) complied with the $3 R$ ("replace, reduce, and refine") experimental design recommendation.

\subsection{Rat model of bone healing}

Experimental details of the procedure to generate a transcortical defect in the proximal rat tibia have been recently reported. ${ }^{12,15}$ In brief, aged rats with or without DM were anaesthetized with intramuscular injection of $25 \mathrm{mg} / \mathrm{kg}$ ketamine and $10 \mathrm{mg} / \mathrm{Kg}$ xylazine. A hole of $2 \mathrm{~mm}$ diameter was then drilled through the cortex, using continuous washing with saline, in both proximal tibial metaphysis. The left and right tibial defect received the unloaded and PTHrPloaded material, respectively, in each rat. Four weeks post-surgery, a period that has been proved insufficient for complete bone regeneration after the same surgical procedure in young rats, ${ }^{15}$ the animals were euthanized using an overdose of ketamine and xylazine, and the long bones were removed and kept frozen at $-20^{\circ} \mathrm{C}$ until processing. 


\subsection{Bone histology and $\mu$-computerized tomography $(\mu \mathrm{CT})$ analysis}

The tibial defects were scanned using GE eXplore Locus $\mu \mathrm{CT}$ scanner (GE Healthcare, London, Canada). Image acquisition was performed at $80 \mathrm{kV}$ and $450 \mu \mathrm{A}$, collecting 400 projections in one full rotation of the gantry. The resulting raw data were reconstructed using a filtered back-projection algorithm to a final image with a resolution of $93 \mu \mathrm{m}$ in all three spatial dimensions. Cubic regions corresponding to cortical or trabecular peri-implant areas with a voxel size of 46 $\mu \mathrm{m}$ in all length, width and height were cropped as the region of interest (ROI). The reconstructed images corresponding to these ROI were viewed and analyzed using MicroView software, version 2.2 with Advanced Bone Analysis plus (GE Healthcare). Bone structural parameters including cortical and trabecular bone volume/tissue volume (\% BV/TV), thickness, bone surface/bone volume ( $\%$ BS/BV) as well as trabecular number and separation were calculated in these areas.

Rat tibiae hosting the different implants were fixed in $10 \%$ neutral formaldehyde for $24 \mathrm{~h}$ followed by $70 \%$ ethanol and subsequently were decalcified with Osteosoft (Merck, Madrid Spain) for 4 weeks, dehydrated and embedded in paraffin using a Leica TP 1020 tissue processor. Histological assessment was performed on saggital $4-\mu \mathrm{m}$ tissue sections around the implant in the tibial metaphysis by Masson's trichromic staining. Bone collagen fibers stains blue (light blue: collagen fibers randomly arranged, characterizing early immature bone; dark blue: trabecular and cortical mature bone), whereas cytoplasm of infiltrating cells at the non-regenerated bone defect displays pale red stain. 


\subsection{Real time PCR}

Total RNA was isolated from the healing rat tibial area with Trizol (Life Technologies, Carlsbad, CA). Gene expression was analyzed by real time PCR using an ABI PRISM 7500 system (Applied Biosystems, Grand Island, NY), as reported. ${ }^{15,20}$ Real time PCR was done using SYBR premix ex Taq (Takara, Otsu, Japan) and the following rat Sost specific primers: 5'GAGTACCCAGAGCCTCCTCA-3' (sense) 5'AGCACACCAACTCGGTGA-3' (antisense). Gene expression of osteocalcin (OC) and vascular endothelial growth factor (VEGF) was analyzed using TaqMan $^{\text {MGB }}$ probes obtained by Assay-by-Design ${ }^{\text {SM }}$ (Applied Biosystems). The housekeeping gene $18 \mathrm{~S}$ rRNA was amplified in parallel with tested genes. Fold change of gene expression was calculated based on the cycle threshold (Ct) value algorithm represented by $2^{-\Delta \Delta \mathrm{Ct}}$, where $\Delta \Delta \mathrm{Ct}=\Delta \mathrm{Ct}_{\text {target gene }}-\Delta \mathrm{Ct}_{18 \mathrm{~s}}$ as described. ${ }^{15}$

\subsection{Statistical Analysis}

Results are expressed as mean \pm SEM. Statistical evaluation was carried out with nonparametric Kruskal-Wallis test and post-hoc Dunn's test or Mann Whitney test, when appropriate. A value of $p<0.05$ was considered significant. 


\section{Results}

\subsection{Changes in bone structure and histology}

Here, we used an experimental rat model showing that a diabetic status, as shown in Fig.1, aggravates the bone structure deterioration related to aging (Table 1). We evaluated the osteoinductive capacity of each PTHrP peptide tested as coated onto a degradable implant to heal a transcortical bone injury in this model. Four weeks following implantation of the unloaded foams, incomplete repair of the bone defect was observed in aged rats, an effect more dramatic in those with DM, as shown by 2D (Fig. 2) and 3D (frontal and sagittal views) (Fig. 3) $\mu \mathrm{CT}$ images. Furthermore, in the diabetic aged rats, the regenerating tibial defect containing the unloaded material showed structural changes including a decrease in cortical BV/TV and cortical thickness but increased cortical BS/BV (Fig. 4), as well as decreased trabecular BV/TV and an increase in both trabecular BS/BV and trabecular separation (Fig. 5), compared to non-diabetic aged controls. In contrast, rats implanted with PTHrP (1-37) or PTHrP (107-111)-loaded foams showed complete healing of the defect in both groups of rats, as depicted by $\mu \mathrm{CT}$ images (Fig. 2 and 3), accompanied by reversal of the aforementioned changes in bone structure parameters (Fig. 4 and 5).

Consistent with these results, histological assessment of the regenerating bone defect area showed abundant newly formed bone tissue around the osteointegrated HA-Gel foam, associated with the implant containing each PTHrP peptide, at the time period evaluated (Fig. 6). 


\subsection{Changes in gene expression}

We also assessed the expression of various osteoblastic genes in the tibial defect during bone regeneration following 4 weeks of biomaterials implantation in both groups of aged rats. Each type of PTHrP-containing foam in these animals was found to induce overexpression of osteocalcin (a late osteoblast differentiation marker) and VEGF (a key angiogenic factor) in the regenerating area (Fig. 7). In addition, the expression of Sost -the gene encoding sclerostin, an important inhibitor of the Wnt pathway with a paramount role as a regulator of bone turnover ${ }^{21}$ - was increased in the diabetic rats during bone repair; but decreased dramatically by the presence of each PTHrP peptide in the implant in aged rats independently of the diabetic status (Fig. 7).

\section{Discussion}

In the present study, we evaluated the ability of two PTHrP-derived peptides to heal a transcortical defect in rats with two prevalent conditions aging and DM- which are prone to skeletal fractures. We show that both peptides tested locally delivered at the injury site were similarly efficient to regenerate this noncritical defect in the tibia of old rats independently of their diabetic status.

In humans over 30-35 years of age, bone mineral density and content starts to decrease, and with further aging, structural changes in bone, including cortical bone volume and trabecular number reduction, trabecular spacing increase and cortical bone thinning become manifest. ${ }^{22}$ Several factors during aging have been proposed to promote these changes including an increase of reactive oxygen species, bone cell senescence induced by shortage of 
telomeres or environmental factors that affect cellular DNA. ${ }^{23} \mathrm{DM}$, being more frequent in the elderly, ${ }^{3}$ is also related to poor bone quality in close relationship with the accumulation of advanced glycosylated end-products (AGEs). ${ }^{24}$ Even though types 1 and 2 DM affect bone differently, ${ }^{25}$ both types have been associated to increased fracture risk due to reduced bone formation. ${ }^{26,27}$

Impaired bone filling of a noncritical defect created at the femoral midshaft was recently observed in obese adult Zucker rats with insulin resistance. ${ }^{28}$ In agreement with these observations, our results show that DM worsens the healing of a bone defect generated in the tibial metaphysis of aged rats, as shown by histological and gene expression evaluation in the bone injury area. Several mechanisms have been proposed to be responsible for these observations such as high glucose-induced deleterious actions on osteoblasts through glycation and oxidation. ${ }^{24,29}$

Current anabolic therapies to prevent osteoporotic fractures prevalent in aging subjects are based on intermittent s.c. administration of PTH-derived peptides. $^{30,31}$ More recently, PTH (1-34) has been further evaluated in various bone repair animal models. ${ }^{32}$ The same type of systemic PTH (1-34) administration as used to increase bone accrual improved endochondral and intramembranous bone regeneration -as occurs after bone fractures and cortical bone injury, respectively- by targeting various stages of bone regeneration. Daily injection of a high dose of PTH (1-34) $(200 \mu \mathrm{g} / \mathrm{Kg})$ enhanced callus formation following a tibial fracture in old rats. ${ }^{33}$ Of note, a lower (75 $\mu \mathrm{g} / \mathrm{kg}$ ) dose of PTH (1-34) per day induced bone regeneration of subcritical femoral defect in type 2 diabetic rats, although less efficiently than in nondiabetic controls. ${ }^{28}$ In addition, daily s.c. injections of a PTHrP analogue based 
on its N-terminal 1-34 sequence (RS-66271), at $10 \mu \mathrm{g} / \mathrm{Kg}$, was effective for preventing impaired healing of a noncritical ulnar defect in rabbits treated with prednisone. ${ }^{34}$ Moreover, either the native $\mathrm{N}$-terminal $\mathrm{PTH}$-like fragment of PTHrP or the PTH-unrelated PTHrP (107-139) peptide systemically administered for two weeks to type 1 diabetic mice accelerated bone regeneration following marrow ablation. ${ }^{12,13}$ We also recently demonstrated the osteoinductive properties of PTHrP (107-111) peptide as coated onto different ceramic implants (including that used here) to fill bone defects in non-diabetic young rats or rabbits. ${ }^{15,16}$

Our present results show that local delivery of PTHrP (1-37) or PTHrP $(107-111)$ by coating a degradable material as implant in a tibial defect cavity induces similar and positive bone regeneration features -affecting both cortical and trabecular compartments in the bone injury healing area- in both nondiabetic and diabetic aged rats. This osteoinductive effect of each PTHrP peptide was accompanied by gene overexpression of OC and VEGF, but downregulation of Sost gene, in the regenerating tibial area of both groups of old rats, consistent with the osteogenic and angiogenic features of PTHrP through its $\mathrm{N}$ - and C-terminal domains. ${ }^{11}$ Of particular interest in this context, Sost antagonism -which promotes predominantly modeling-based bone formation at trabecular and cortical bone surfaces ${ }^{35}$ - has been proven effective to promote bone regeneration in rats with type $2 \mathrm{DM}^{28}$

Local delivery of PTHrP peptides at the injured area as used here might facilitate reaching their bone cell targets and thus increase their efficacy compared to systemic therapy. In fact, consistent with previous in vitro data using PTHrP (107-111)-coated on various bioceramics -including the same 
ceramic foam as the one used here as carrier ${ }^{15}-$, PTHrP (1-37) was also rapidly released from the material into the surrounding medium. Assuming similar release kinetics for each $\mathrm{PTHrP}$ peptide in our in vivo setting, no significant amount of each peptide is likely to remain in the implant after 5 days; supporting the current idea that an initial burst of each PTHrP peptide might be sufficient to improve bone healing. ${ }^{15,16}$ PTHrP acts as a pivotal endogenous stimulator of bone formation through autocrine, paracrine and even intracrine actions on committed osteoblast precursors enhancing their differentiation and reducing osteoblast apoptosis. ${ }^{36}$ For PTHrP to play such predominant role on osteoblast differentiation and survival, control mechanisms must exist to ensure that only short-lived, high levels of PTHrP are available to local targets, since persistently increased local PTHrP levels -as occurs for PTH in hyperparathyroid patientswould favor increased osteoclastogenesis. ${ }^{11}$ Interestingly, in this regard, PTHrP haploinsufficiency has been shown to impair healing of a mid-femur fracture in mice. ${ }^{37}$ Our results support the validity of a strategy based on the local delivery of the PTHrP peptides tested to promote bone regeneration in the setting of DM- and age-related osteopenia.

\section{Conclusions}

The present study demonstrates that delivery of either PTHrP (1-37) or PTHrP (107-111) from degradable HA-Gel implants to a noncritical tibial defect counteracts the adverse effects imposed by age and DM on bone regeneration in rats. Our findings suggest the suitability of this strategy to promote bone healing in both conditions. 


\section{Acknowledgements}

We thank Prof. Jesús Tresguerres (School of Medicine, Universidad Complutense, Madrid) for plasma insulin determination. This research was supported by grants from the Instituto de Salud Carlos III (PI11/00449 and RETICEF RD12/0043/0008) and Comunidad Autónoma de Madrid (S2009/MAT-1472). JAA, SP-N and DL are recipients of post-doctoral research contracts from Ministerio de Ciencia e Innovación-Juan de la Cierva program (JCI-2011-09548), RETICEF (RD06/0013/1002 and RD12/0043/0008) and from Ministerio de Economía y Competitividad (FPDI-2013-17268), respectively. ALH was supported by Ministerio de Educación-FPU program (AP2009-1871).

\section{Disclosures}

All the authors declared no competing interests.

\section{References}

1. Ensrud KE, Palermo L, Black DM, Cauley J, Jergas M, Orwoll ES, Nevitt, MC, Fox KM, Cummings SR. Hip and calcaneal bone loss increase with advancing age: longitudinal results from the study of osteoporotic fractures. J Bone Miner Res 1995;10:1778-1787.

2. van den Bergh JP, van Geel TA, Geusens PP. Osteoporosis, frailty and fracture: implications for case finding and therapy. Nat Rev Rheumatol 2012;8:163-172.

3. Tyrovolas S, Koyanagi A, Garin N, Olaya B, Ayuso-Mateos JL, Miret M, Chatterji S, Tobiasz-Adamczyk B, Koskinen S, Leonardi M, Haro JM. Diabetes mellitus and its association with central obesity and disability among older adults: a global perspective. Exp Gerontol 2015;64:70-77. 
4. Hamann C, Rauner M, Höhna Y, Bernhardt R, Mettelsiefen J, Goettsch C, Günther KP, Stolina M, Han CY, Asuncion FJ, Ominsky MS, Hofbauer LC. Sclerostin antibody treatment improves bone mass, bone strength, and bone defect regeneration in rats with type 2 diabetes mellitus. J Bone Miner Res 2013;28:627-638.

5. Janghorbani M, Van Dam RM, Willett WC, Hu FB. Systematic review of type 1 and type 2 diabetes mellitus and risk of fracture. Am $\mathrm{J}$ Epidemiol 2007;166:495-505.

6. Schwartz AV, Vittinghoff E, Bauer DC, Hillier TA, Strotmeyer ES, Ensrud KE, Donaldson MG, Cauley JA, Harris TB, Koster A, Womack CR, Palermo L, Black DM. Association of BMD and FRAX score with risk of fracture in older adults with type 2 diabetes. JAMA 2011;305:2184-2192.

7. Salinas AJ, Esbrit P, Vallet-Regí M. A tissue engineering approach based on the use of bioceramics for bone repair. Biomater Sci 2013;1:40-51.

8. Gothard D, Smith EL, Kanczler JM, Rashidi H, Qutachi O, Henstock J, Rotherham M, El Haj A, Shakesheff KM, Oreffo RO. Tissue engineered bone using select growth factors: A comprehensive review of animal studies and clinical translation studies in man. Eur Cell Mater 2014; 28:166-207.

9. Schieker M, Seitz H, Drosse I, Seitz S, Mutschler W. Biomaterials as scaffold for bone tissue engineering. European Journal of Trauma 200;32:114-124.

10. Fenton AJ, Kemp BE, Hammonds RG, Mitchelhill K, Moseley JM, Martin TJ, Nicholson GC. A potent inhibitor of osteoclastic bone resorption within a highly conserved pentapeptide region of parathyroid hormone-related protein, PTHrP (107-111). Endocrinology 1991;129:3424-3426. 
11. Esbrit P, Alcaraz MJ. Current perspectives on parathyroid hormone (PTH) and PTH-related protein (PTHrP) as bone anabolic therapies. Biochem Pharmacol 2013; 85:1417-1423.

12. Lozano D, de Castro LF, Dapía S, Andrade-Zapata I, Manzarbeitia F, Alvarez-Arroyo MV, Gómez-Barrena E, Esbrit P. Role of parathyroid hormone-related protein in the decreased osteoblast function in diabetesrelated osteopenia. Endocrinology 2009;150:2027-2035.

13. Lozano D, Fernández-de-Castro L, Portal-Núñez S, López-Herradón A, Dapía S, Gómez-Barrena E, Esbrit P. The C-terminal fragment of parathyroid hormone-related peptide promotes bone formation in diabetic mice with low-turnover osteopaenia. Br J Pharmacol 2011;162:1424-1438.

14. Rodríguez-de la Rosa L, López-Herradón A, Portal-Núñez S, Murillo-Cuesta S, Lozano D, Cediel R, Varela-Nieto I, Esbrit P. Treatment with N- and Cterminal peptides of parathyroid hormone-related protein partly compensate the skeletal abnormalities in IGF-I deficient mice. PLoS One 2014;9:e87536.

15. Lozano D, Sánchez-Salcedo S, Portal-Núñez S, Vila M, López-Herradón A, Ardura JA, Mulero F, Gómez-Barrena E, Vallet-Regí M, Esbrit P. Parathyroid hormone-related protein (107-111) improves the bone regeneration potential of gelatin-glutaraldehyde biopolymer-coated hydroxyapatite. Acta Biomater 2014; 10:3307-3316.

16. Trejo CG, Lozano D, Manzano M, Doadrio JC, Salinas AJ, Dapía S, GómezBarrena E, Vallet-Regí M, García-Honduvilla N, Buján J, Esbrit P. The osteoinductive properties of mesoporous silicate coated with osteostatin in a rabbit femur cavity defect model. Biomaterials 2010; 31:8564-8573. 
17. Cicuéndez M, Izquierdo-Barba I, Sánchez-Salcedo S, Vila M, Vallet-Regí M. Biological performance of hydroxyapatite-biopolymer foams: in vitro cell response. Acta Biomater 2012; 8:802-810.

18. Portha B, Picon L, Rosselin G. Chemical diabetes in the adult rat as the spontaneous evolution of neonatal diabetes. Diabetologia 1979;17:371-377.

19. Nuche-Berenguer B, Moreno P, Esbrit P, Dapía S, Caeiro JR, Cancelas J, Haro-Mora JJ, Villanueva-Peñacarrillo ML. Effect of GLP-1 treatment on bone turnover in normal, type 2 diabetic, and insulin-resistant states. Calcif Tissue Int 2009; 84:453-461.

20. García-Martín A, Ardura JA, Maycas M, Lozano D, López-Herradón A, Portal-Núñez S, García-Ocaña A, Esbrit P. Functional roles of the nuclear localization signal of parathyroid hormone-related protein $(\mathrm{PTHrP})$ in osteoblastic cells. Mol Endocrinol 2014; 28:925-934.

21. Kim JB, Leucht P, Lam K, Luppen C, Berge DT, Nusse R, Helms JA. Bone regeneration is regulated by Wnt signaling. J Bone Miner Res 2007;22:19131923.

22. Majumdar S, Genant HK, Grampp S, Newitt DC, Truong VH, Lin JC, Mathur A. Correlation of trabecular bone structure with age, bone mineral density, and osteoporotic status: in vivo studies in the distal radius using high resolution magnetic resonance imaging. J Bone Miner Res 1997;12:111118.

23. Boskey AL, Coleman R. Aging and bone. J Dent Res 2010; 89:1333-1348.

24. Blakytny R, Spraul M, Jude EB. The diabetic bone: a cellular and molecular perspective. Int J Low Extrem Wounds 2011; 10:16-32. 
25. Hofbauer LC, Brueck CC, Singh SK, Dobnig H. Osteoporosis in patients with diabetes mellitus. J Bone Miner Res 2007; 22:1317-1328.

26. Conti F, Wolosinska DT, Pugliese G. Diabetes and bone fragility: a dangerous liaison. Aging Clin Exp Res 2013; 25:S39-41.

27. Hamann C, Kirschner S, Günther KP, Hofbauer LC. Bone, sweet bone-osteoporotic fractures in diabetes mellitus. Nat Rev Endocrinol 2012; 8:297305.

28. Hamann C, Picke AK, Campbell GM, Balyura M, Rauner M, Bernhardt R, Huber G, Morlock MM, Günther KP, Bornstein SR, Glüer CC, Ludwig B, Hofbauer LC. Effects of parathyroid hormone on bone mass, bone strength, and bone regeneration in male rats with type 2 diabetes mellitus. Endocrinology 2014;155:1197-1206.

29. Saito M, Fujii K, Soshi S, Tanaka T. Reductions in degree of mineralization and enzymatic collagen cross-links and increases in glycation-induced pentosidine in the femoral neck cortex in cases of femoral neck fracture. Osteoporos Int 2006;17:986-995.

30. Greenspan SL, Bone HG, Ettinger MP, Hanley DA, Lindsay R, Zanchetta JR, Blosch CM, Mathisen AL, Morris SA, Marriott TB. Effect of recombinant human parathyroid hormone (1-84) on vertebral fracture and bone mineral density in postmenopausalwomenwith osteoporosis: a randomized trial. Ann Intern Med 2007;146:326-339.

31. Neer RM, Arnaud CD, Zanchetta JR, Prince R, Gaich GA, Reginster JY, Hodsman AB, Eriksen EF, Ish-Shalom S, Genant HK, Wang O, Mitlak BH. Effect of parathyroid hormone (1-34) on fractures and bone mineral density 
in postmenopausal women with osteoporosis. N Engl J Med 2001;344:14341441.

32. Takahata, M, Awad HA, O’Keefe RJ, Bukata SV, Schwarz EM. Endogenous tissue engineering: PTH therapy for skeletal repair. Cell Tissue Res 2012;347:545-552.

33. Andreassen TT, Fledelius C, Ejersted C, Oxlund H. Increases in callus formation and mechanical strength of healing fractures in old rats treated with parathyroid hormone. Acta Orthop Scand 2001;72:304-307.

34. Bostrom MP, Gamradt SC, Asnis P, Vickery BH, Hill E, Avnur Z, Waters RV. Parathyroid hormone-related protein analog RS-66271 is an effective therapy for impaired bone healing in rabbits on corticosteroid therapy. Bone 2000;26:437-442.

35. Ominsky MS, Niu QT, Li C, Li X, Ke HZ. Tissue-level mechanisms responsible for the increase in bone formation and bone volume by sclerostin antibody. J Bone Miner Res 2014; 29:1424-1430.

36. Miao D, He B, Jiang Y, Kobayashi T, Sorocéanu MA, Zhao J, Su H, Tong X, Amizuka N, Gupta A, Genant HK, Kronenberg HM, Goltzman D, Karaplis AC. Osteoblast-derived PTHrP is a potent endogenous bone anabolic agent that modifies the therapeutic efficacy of administered PTH 1-34. J Clin Invest 2005;115:2402-2411.

37. Wang YH, Qiu Y, Han XD, Xiong J, Chen YX, Shi HF, Karaplis A. Haploinsufficiency of endogenous parathyroid hormone-related peptide impairs bone fracture healing. Clin Exp Pharmacol Physiol 2013;40:715-723. 


\section{Figure legends}

Fig. 1. DM-related parameters $(A-C)$ and body weight (D) in old and diabetic rats and in old nondiabetic controls. Experimental details are described in Materials and Methods. Results are mean $\pm \operatorname{SEM}(n=10) .{ }^{*} p<0.05$ vs old (nondiabetic) controls.

Fig. 2. Representative $2 \mathrm{D}$ images by $\mu \mathrm{CT}$ of the proximal tibial metaphysis comprising the defect area with the different HA-Gel implants, containing or not PTHrP (1-37) or PTHrP (107-111) at 4 weeks after surgery in old rats with or without DM. Images show cortical (solid square) or trabecular (dotted square) peri-implant regions where the regions of interest (ROIs) were acquired. Arrows denote the areas were the defect was performed.

Fig. 3. Representative 3D images by $\mu \mathrm{CT}$ of the area surrounding the different HA-Gel implants, containing or not PTHrP (1-37) or PTHrP (107-111) at 4 weeks after surgery in aged rats with or without DM. The upper row shows a frontal view of the bone defect, while the lower row depicts a sagittal view of the inner cortical bone structure surrounding the defect, clearly indicating that bone regeneration is improved in the presence of the PTHrP peptides.

Fig. 4. Bone cortical parameters in the rat tibial defect holding each type of HAGel implant in old and diabetic rats and in old nondiabetic controls. Results are mean $\pm \operatorname{SEM}(n=5) .{ }^{*} p<0.05$ vs unloaded scaffold in nondiabetic controls; ${ }^{a} p<0.05$ vs unloaded implant in diabetic rats.

Fig. 5. Bone trabecular parameters in the healing tibial defect containing each type of HA-Gel implant in old diabetic rats and in old nondiabetic controls. Results are mean \pm SEM $(n=5) .{ }^{*} p<0.05$ vs unloaded scaffold in nondiabetic 
controls; ${ }^{a} p<0.05$ vs unloaded implant in diabetic rats.

Fig. 6. Representative light microscopy images of Masson's stained tissue sections corresponding to the area surrounding the different HA-Gel implants at 4 weeks after implantation into a transcortical defect in the rat tibia of old rats with or without DM. BD = Bone defect; NB = Newly formed bone. Arrows show the presence of residual HA-Gel material (inset).

Fig. 7. Changes in gene expression (by real time PCR) of bone-related factors in the regenerating tibial defect at 4 weeks after implantation of the different scaffolds (HA-Gel) with or without each PTHrP peptide in old and diabetic rats and in old nondiabetic controls. Results are mean \pm SEM $(n=5)$. * $p<0.05$ vs unloaded scaffold in non diabetic controls; ${ }^{a} p<0.05$ vs unloaded scaffold in diabetic rats.

\section{Supplementary Figure Legends}

Supplementary Fig. 1. Representative digital (A) and scanning electron microscope (B) images of HA-Gel foams.

Table 1. Histomorphometric analysis at the distal femoral metaphysis of aged rats, with or without DM, and younger rats as age control.

\begin{tabular}{|c|c|c|c|}
\hline & Young control & Old control & Old diabetic \\
\hline \hline BV/TV (\%) & $29.71 \pm 1.01$ & $24.34 \pm 1.44^{*}$ & $17.48 \pm 1.89^{* *, \#}$ \\
\hline Trabecular thickness $(\boldsymbol{\mu m})$ & $133.45 \pm 7.34$ & $146.87 \pm 15.08$ & $104.88 \pm 9.36^{*, \#}$ \\
\hline Trabecular separation $(\boldsymbol{\mu m})$ & $307.25 \pm 8.66$ & $432.69 \pm 61.36^{*}$ & $577.15 \pm 36.64^{* *}$ \\
\hline Trabecular number & $2.24 \pm 0.09$ & $1.75 \pm 0.17^{*}$ & $1.63 \pm 0.14^{*}$ \\
\hline
\end{tabular}

Results are mean \pm SEM $(n=5)$. ${ }^{*} p<0.05 ;{ }^{* *} 0.01$ vs the corresponding younger group; ${ }^{\mathrm{p}}<0.05$ vs old nondiabetic control. 
A
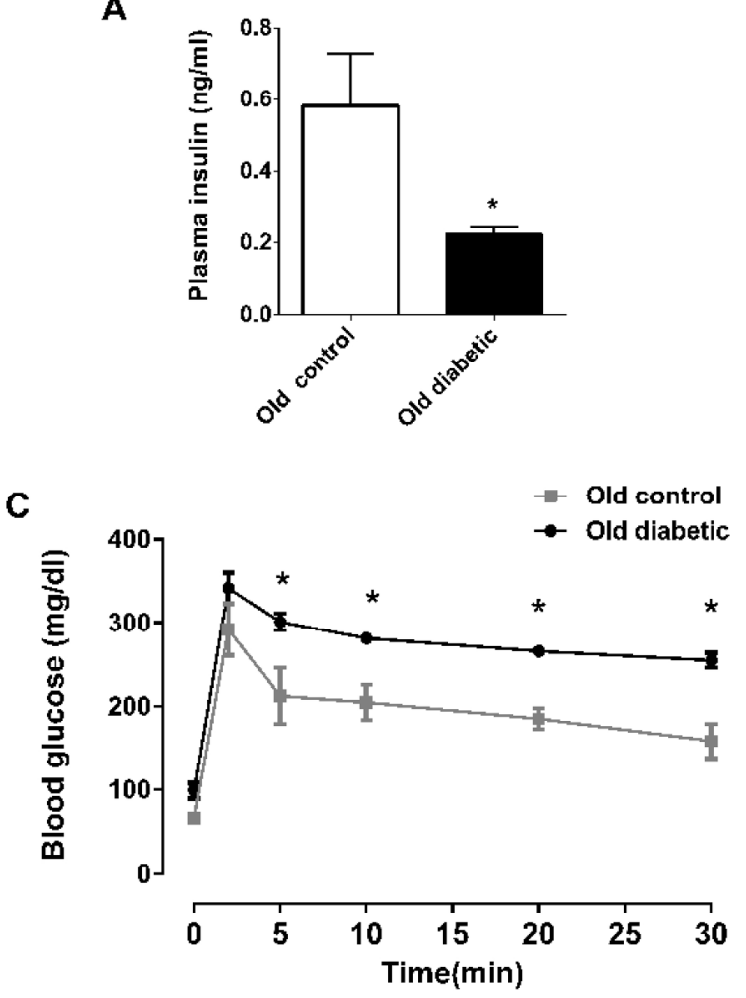

B

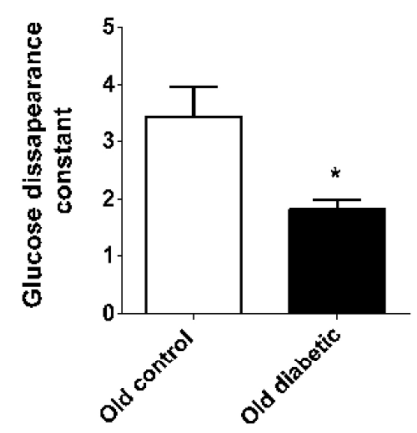

D

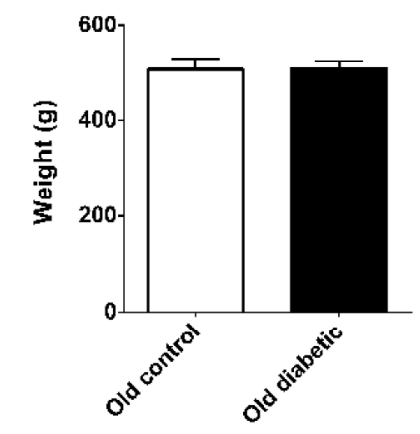

Figure 1

$121 \times 99 m m(600 \times 600$ DPI $)$

John Wiley \& Sons, Inc. 


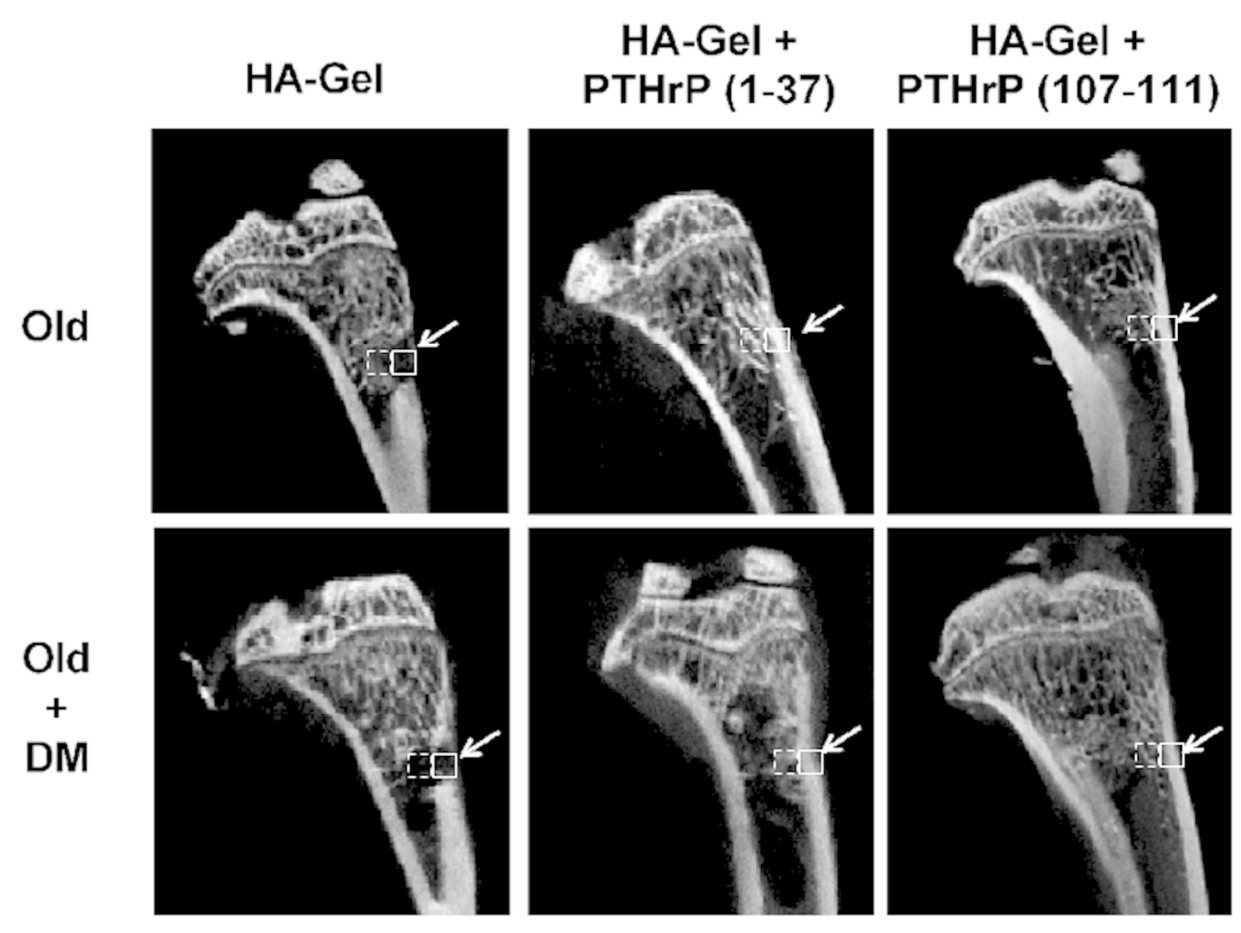

Figure 2

$261 \times 197 \mathrm{~mm}(300 \times 300 \mathrm{DPI})$

John Wiley \& Sons, Inc. 


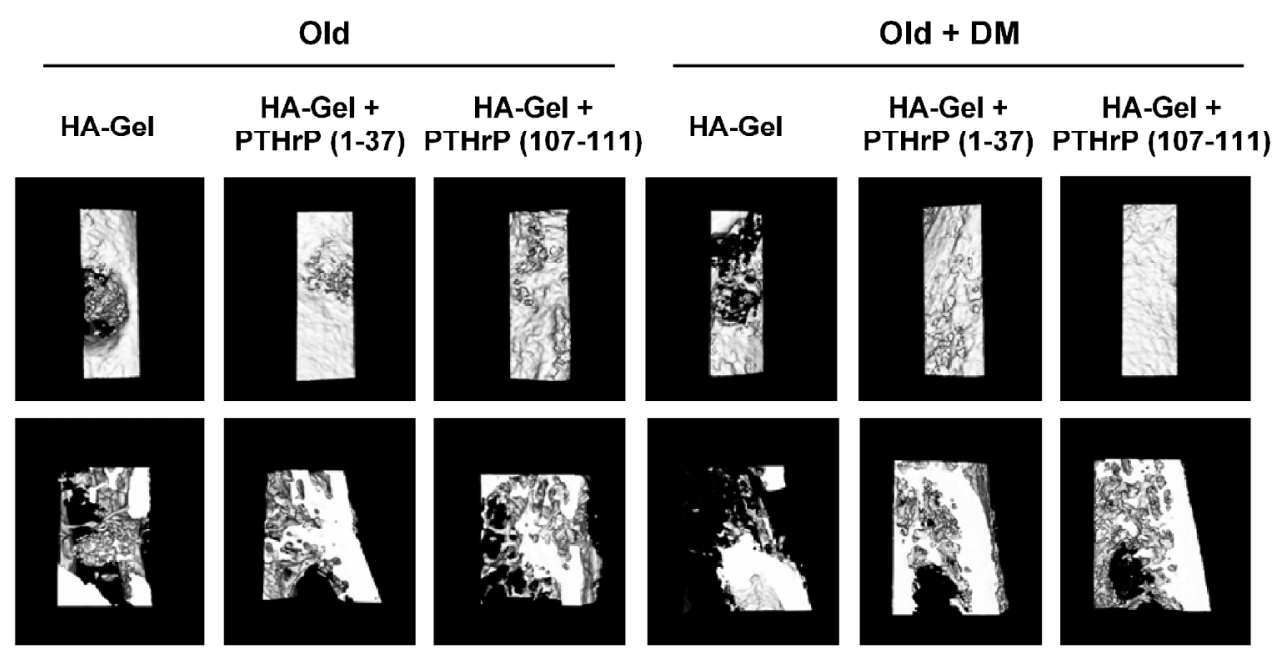

Figure 3

$176 \times 90 \mathrm{~mm}(300 \times 300 \mathrm{DPI})$

John Wiley \& Sons, Inc. 
1

2

3

4

5

6

7

8

9

10

11

12

13

14

15

16

17

18

19

20

21

22

23

24

25

26

27

28

29

30

31

32

33

34

35

36

37

38

39

40

41

42

43

44

45

46

47

48

49

50

51

52

53

54

55

56

57

58

59

60

A

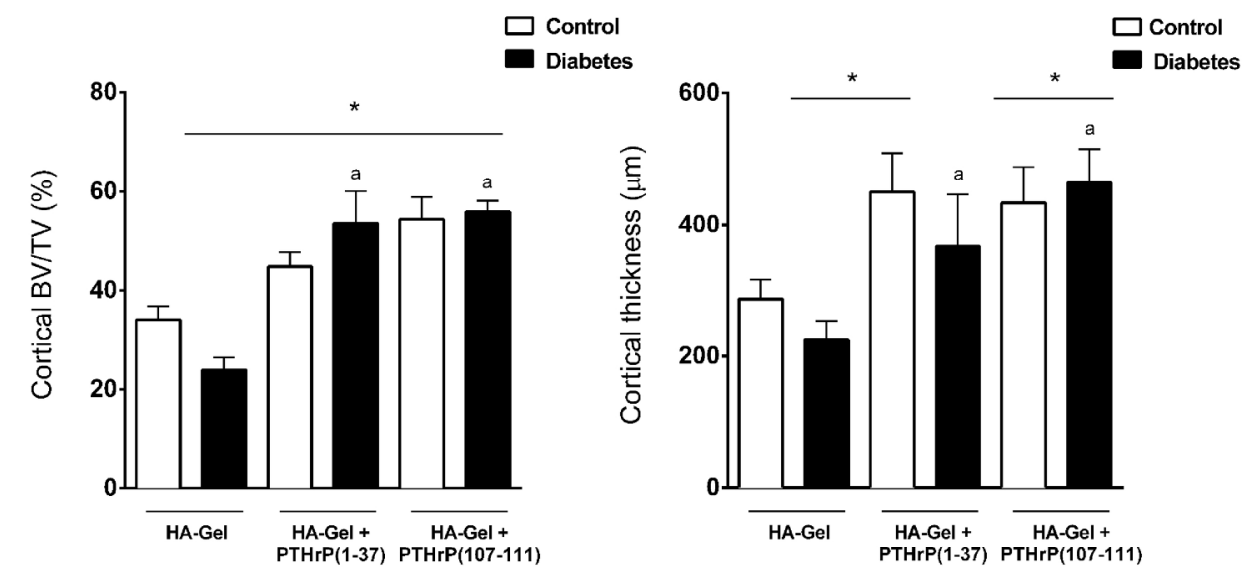

\section{C}
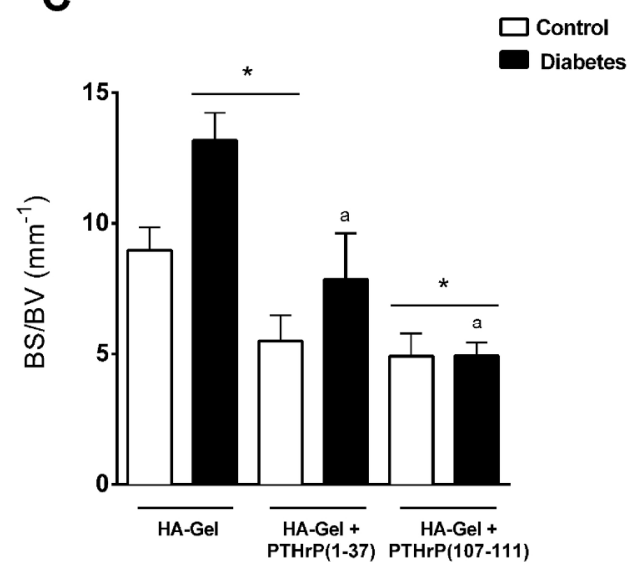

Figure 4.

$111 \times 117 \mathrm{~mm}(600 \times 600$ DPI $)$

John Wiley \& Sons, Inc. 

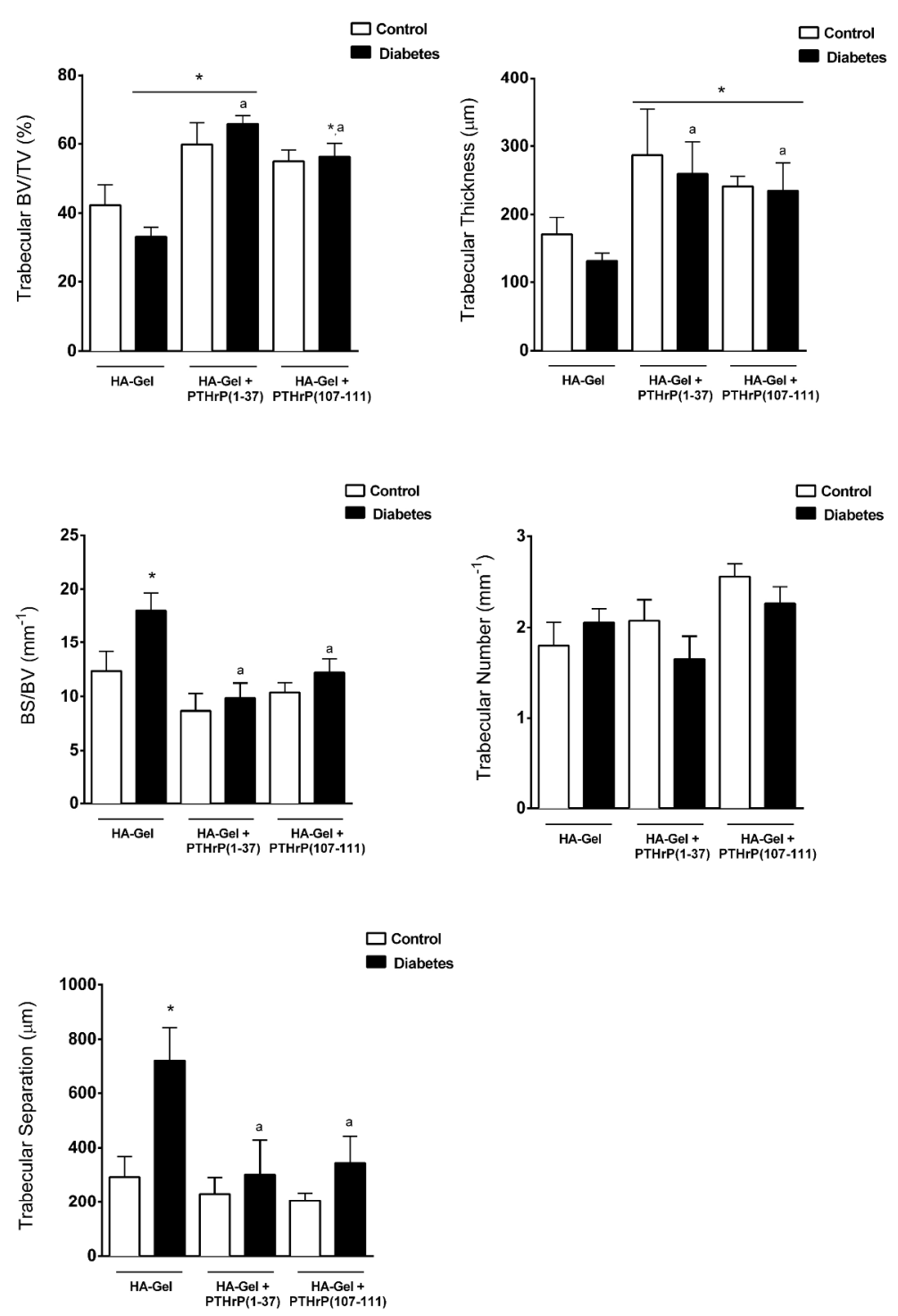

Figure 5

$127 \times 183 \mathrm{~mm}(600 \times 600 \mathrm{DPI})$

50

51

52

53

54

55

56

57

58

59

60

John Wiley \& Sons, Inc. 


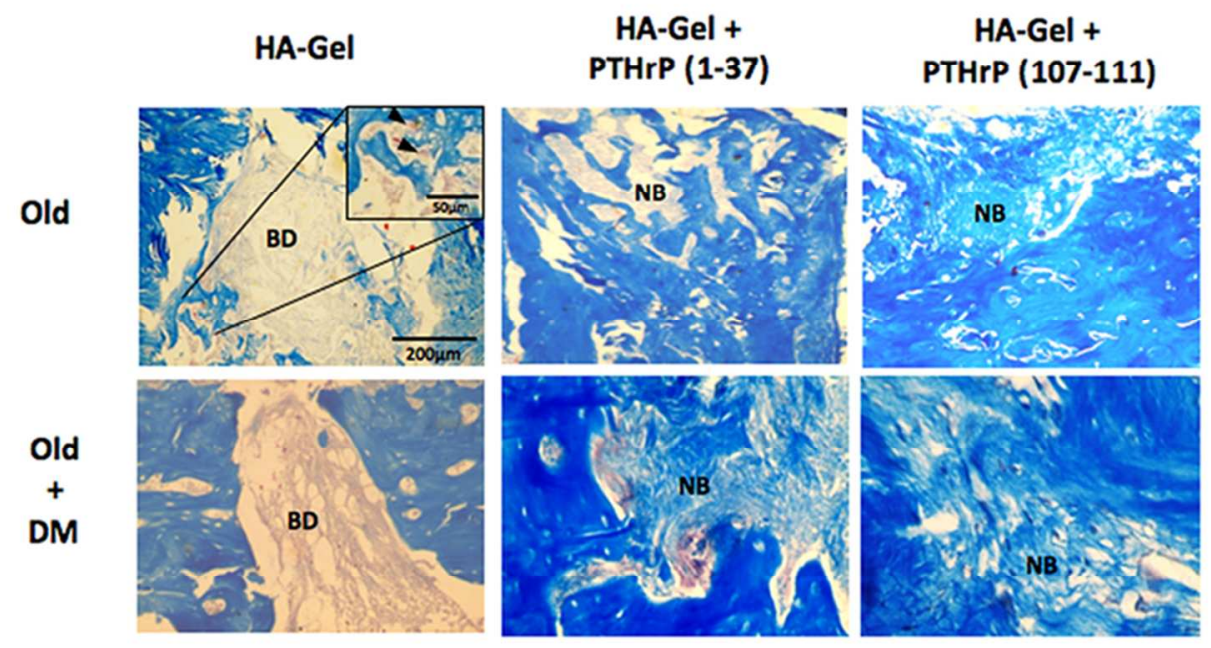

Figure 6

$83 \times 49 \mathrm{~mm}(300 \times 300$ DPI $)$

John Wiley \& Sons, Inc. 


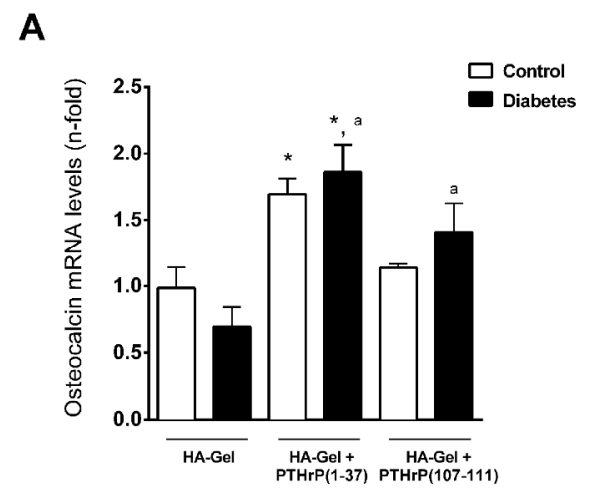

B

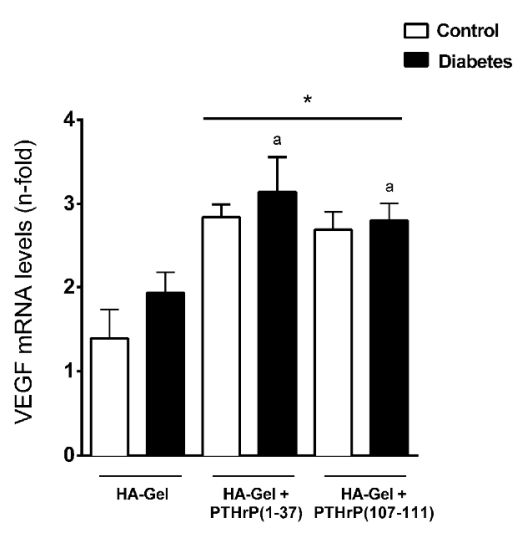

C

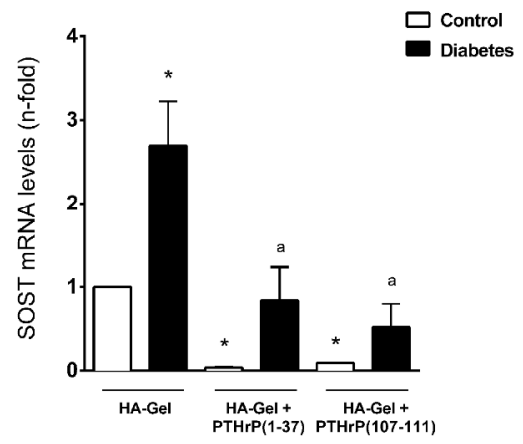

Figure 7

$105 \times 263 \mathrm{~mm}(600 \times 600$ DPI $)$

John Wiley \& Sons, Inc. 